\title{
CLTをドリフトピン接合し耐震壁として挿入した鉄骨架構の構造性能 STRUCTURAL PERFORMANCE OF COMPOSITE STRUCTURE WITH CLT WALL INFILLED IN STEEL FRAMES USING DRIFT-PIN WITH STEEL PLATE
}

\author{
金澤 和寿美*1, 五十田 博*2, 北 守顕 久*3, 宇佐美 徹*4, 荒 木 康 弘*5 \\ Kazumi KANAZAWA, Hiroshi ISODA, Akihisa KITAMORI, \\ Tetsu USAMI and Yasuhiro ARAKI
}

\begin{abstract}
The purpose of this research is to confirm the structural performance of steel frame with CLT shear wall using drift-pin joint by conducting $1 / 2$ scale experiment, joint test and material test, and to make analysis model which follows the experimental results. In 1/2 scale experiment, total of four specimen in different strength grade of CLT or insertion position as parameters are tested. Incremental analysis was conducted by using FEM analysis software to model a steel frame, CLT panel, spring of drift-pin joint, and CLT compression spring. The result of incremental analysis reproduces the experimental results accurately.
\end{abstract}

Keywords : Cross Laminated Timber, Shear Wall, Composite Structure, Drift-pin Joint, FEM Analysis CLT, 而震壁, 混構造, ドリフトピン接合, FEM 解析

\section{1. はじめに}

クロス・ラミネイティド・ティンバー (Cross Laminated Timber、 以下 CLT と称する) は、ひき板の各層を繊維方向が互いに直交する ように積層接着した版で、寸法安定性を確保したうえで、比較的高 耐力を発現しうる。また、強度的に低質な材を内層部に利用するこ とで木材需要の増加が想定されるため、木質構造における新たな建 築用材として注目されている。海外では、特に欧州を中心に実用化 されており、比較的大空間の構造で水平構面として利用されるばか りでなく、現在では 20 階建てにも及ぶ高層建物の壁床等にも利用 されている。日本では 2014 年に JAS（日本農林規格）が施行され、 2016 年に基準強度や CLT パネル工法として告示が制定された。

CLT は比較的高耐力と書いたが、強軸の面内圧縮、面内曲げとも に繊維方向に比べ強度の低い繊維直交方向が介在するため、いわゆ る強軸の強度自体は繊維平行方向に比べ低下している。一方で、せ 几断性能は、繊維平行と直角方向が組み合わさったとしても強度低 下はわずかであり、積層数や構成される幅方向のラミナの数にもよ るが、スギ集成材の強度 $2.7 \mathrm{~N} / \mathrm{mm}^{2}$ をほぼ維持している。この CLT の高いせん断耐力を活か寸方法が耐震壁としての利用である。特に、 引張接合部の負担が少なくなるよう、鉄骨造や鉄筋コンクリート造 柱はり構造との組み合わせは利点があると予想される。また、CLT が鉛直荷重を支持せず、内装制限などの耐火要件がなく、さらに接
合部を通じて主体構造への有害な熱の流入が認められない接合形式 の場合には、CLTをあらわしで使用することもできる。既往研究で も鉄骨造との組み合わせについて、接合部の実験と解析的な手法に より、新築鉄骨造への CLT 耐震壁の適用検討がされている 1)。これ までにも鉄骨架構と CLT 耐震壁を組み合わせた構造について構造 実験と解析を含む研究がなされているが、CLT 耐震壁と鉄骨架構の 接合に引きボルトを用いた接合方式 2)や、鉄骨架構の柱はりがピン 接合で CLT 耐震壁と鉄骨架構の接合部に用いる鋼板を塑性変形さ せる接合方式 3)となっており、柱はりが剛接合された鉄骨架構に鋼 板挿入ドリフトピン接合を用いて CLT 耐震壁が挿入された構造の 知見は極めて少ない。

そこで、本研究では CLT 耐震壁と鉄骨架構の構面について、1/2 スケールの縮小実験を行い、その挙動を把握する。CLT と鉄骨架構 の接合は CLT 表面へ鋼材の露出が極力ない鋼板挿入ドリフトピン 接合とした。また、その構面実験を再現する有限要素モデルを作成 し、実験結果との整合性を確認した。

\section{2. 試験体の設計}

試験体の設計は非木造率の高い都市部の一般的な事務所建築を想 定し、鉄骨のはりが先行して降伏することを前提として次のような 手順で行った。

\footnotetext{
侏竹中工務店技術研究所（元 京都大学大学院）修士（農学） R.\&D. Institute, Takenaka Co., M.Agr. 京都大学生存圈研究所 教授・博士（工学） Prof., RISH, Kyoto University, Dr.Eng.

大阪産業大学工学部 准教授・博士 (農学)

(株竹中工務店技術研究所 博士 (工学)

国土技術政策総合研究所 主任研究官·博士 (工学)

Assoc. Prof., Faculty of Engineering, Osaka Sangyo University, Dr.Agr.

R.\&D. Institute, Takenaka Co., Dr.Eng.

Senior Researcher, NILIM, Dr.Eng.
} 
Table 1 Results of parametric study: Horizontal load-carrying capacity

\begin{tabular}{|c|c|c|c|c|c|c|c|c|c|c|c|c|c|}
\hline \multicolumn{2}{|c|}{ Layer-ply type } & \multicolumn{4}{|c|}{ 5layers-5plies $(D=150)$} & \multicolumn{4}{|c|}{ 5layers-7plies $(D=210)$} & \multicolumn{4}{|c|}{ 7layers-7plies $(D=210)$} \\
\hline \multirow{2}{*}{$\begin{array}{l}\text { Strength } \\
\text { grade }\end{array}$} & \multirow{2}{*}{$\begin{array}{l}\text { Height }(\mathrm{mm}) \\
\text { Width }(\mathrm{mm})\end{array}$} & \multicolumn{2}{|c|}{\begin{tabular}{l|l}
3000 \\
\end{tabular}} & \multicolumn{2}{|c|}{4000} & \multicolumn{2}{|c|}{3000} & \multicolumn{2}{|c|}{4000} & \multicolumn{2}{|c|}{3000} & \multicolumn{2}{|c|}{4000} \\
\hline & & $Q_{S}(\mathrm{kN})$ & $Q_{M}(\mathrm{kN})$ & $Q_{S}(\mathrm{kN})$ & $Q_{M}(\mathrm{kN})$ & $Q_{S}(\mathrm{kN})$ & $Q_{M}(\mathrm{kN})$ & $Q_{S}(\mathrm{kN})$ & $Q_{M}(\mathrm{kN})$ & $Q_{S}(\mathrm{kN})$ & $Q_{M}(\mathrm{kN})$ & $Q_{S}(\mathrm{kN})$ & $Q_{M}(\mathrm{kN})$ \\
\hline \multirow{2}{*}{$\mathrm{S} 60$} & 1200 & 486.0 & 233.3 & 486.0 & 175.0 & 680.4 & 388.8 & 680.4 & 291.6 & 680.4 & 311.0 & 680.4 & 233.3 \\
\hline & 2400 & 972.0 & 933.1 & 972.0 & 699.8 & 1360.8 & 1555.2 & 1360.8 & 1166.4 & 1360.8 & 1244.2 & 1360.8 & 933.1 \\
\hline \multirow{3}{*}{ S90 } & 1200 & 486.0 & 298.1 & 486.0 & 223.6 & 680.4 & 496.8 & 680.4 & 372.6 & 680.4 & 397.4 & 680.4 & 298.1 \\
\hline & 1800 & 729.0 & 670.7 & 729.0 & 503.0 & 1020.6 & 1117.8 & 1020.6 & 838.4 & 1020.6 & 894.2 & 1020.6 & 670.7 \\
\hline & 2400 & 972.0 & 1192.3 & 972.0 & 894.2 & 1360.8 & 1987.2 & 1360.8 & 1490.4 & 1360.8 & 1589.8 & 1360.8 & 1192.3 \\
\hline \multirow{3}{*}{ Mx60 } & 1200 & 486.0 & 194.4 & 486.0 & 145.8 & 680.4 & 349.9 & 680.4 & 262.4 & 680.4 & 233.3 & 680.4 & 175.0 \\
\hline & 1800 & 729.0 & 437.4 & 729.0 & 328.1 & 1020.6 & 787.3 & 1020.6 & 590.5 & 1020.6 & 524.9 & 1020.6 & 393.7 \\
\hline & 2400 & 972.0 & 777.6 & 972.0 & 583.2 & 1360.8 & 1399.7 & 1360.8 & 1049.8 & 1360.8 & 933.1 & 1360.8 & 699.8 \\
\hline \multirow{3}{*}{ Mx90 } & 1200 & 486.0 & 231.8 & 486.0 & 173.9 & 680.4 & 386.4 & 680.4 & 289.8 & 680.4 & 265.0 & 680.4 & 198.7 \\
\hline & 1800 & 729.0 & 521.6 & 729.0 & 391.2 & 1020.6 & 869.4 & 1020.6 & 652.1 & 1020.6 & 596.2 & 1020.6 & 447.1 \\
\hline & 2400 & 972.0 & 927.4 & 972.0 & 695.5 & 1360.8 & 1545.6 & 1360.8 & 1159.2 & 1360.8 & 1059.8 & 1360.8 & 794.9 \\
\hline
\end{tabular}

(1)鉄骨架構の柱はり断面とモジュールを決定

スパン $7.2 \mathrm{~m}$ 、階高 $4.0 \mathrm{~m} 、 7$ 階建てのオフィスビルを想定し、柱 は $\square-500 \times 500 \times 19 （$ BCR295）、はりは H-600×300× $12 \times 22$ (SN490B) とした。

(2)CLT の種類を決定

強度等級の異なる CLT パネルについて、保有水平耐力に対する 幅・高さの影響を検討した。高さ方向を強軸方向とし、ラミナ厚を すべて $30 \mathrm{~mm}$ 、強度等級 $(\mathrm{S} 60 / \mathrm{S} 90 / \mathrm{Mx} 60 / \mathrm{Mx} 90)$ 、層プライ種類 $(5$ 層 5 プライ/5 層 7 プライ/7 層 7 プライ)、CLT 幅 $W$ $(1200 \mathrm{~mm} / 1800 \mathrm{~mm} / 2400 \mathrm{~mm}) 、$ CLT 高さ $H(3000 \mathrm{~mm} / 4000 \mathrm{~mm})$ をパラメータとして以下の計算式 $(D$ は CLT 厚さ $(\mathrm{mm}))$ により保 有水平耐力を求めた。ここで、CLT の端部は固定されており、反曲 点位置はパネル高さ中央にあるとした。

$$
\begin{array}{lll}
\text { 保有水平耐力 } Q(\mathrm{kN}) & : \min \left\{Q_{S}, Q_{M}\right\} \\
\text { せん断耐力 } Q_{S}(\mathrm{kN}) & : & F_{S} \times W \times D \times 10^{-3} \\
\text { 曲げ耐力 } Q_{M}(\mathrm{kN}) & : & \frac{2 M}{H} \times 10^{-3} \\
\text { 曲げモーメント } M(\mathrm{kN}) & : & \frac{D \times W^{2} \times F_{b}}{6} \times 10^{-6}
\end{array}
$$

面内せん断基準強度 $F_{s}\left(\mathrm{~N} / \mathrm{mm}^{2}\right)$ は CLT のせん断破壊モードをす べてモード I と仮定して 2.7 とし、面内強軸曲げ基準強度 $F_{b}$ $\left(\mathrm{N} / \mathrm{mm}^{2}\right)$ はCLT を用いた建築物の設計施工マニュアル』4)に記載 の方法で算出した。すべてのパラメータで求まる結果を Table 1 に 示す。各パラメータの場合のせん断耐力 $Q_{S}$ と曲げ耐力 $Q_{M}$ の計算結 果を示し、保有水平耐力となる結果を網掛けとしている。大半の場 合、曲げにて強度が決定している。特に 5 層 5 プライ、 7 層 7 プラ イは S90 の場合の一部を除きすべて曲げで決定し、曲げ耐力とせん 断耐力の差が大きいケースもあり、効率があまりょくないことが分 かる。また、 $\mathrm{S}$ (同一等級構成) と $\mathrm{Mx}$ (異等級構成) の比較では $\mathrm{S}$ のほうが面内曲げは強くなる。以上の結果から、現在入手可能なこ とを考慮し、強度等級 $\mathrm{S} 90$ で 5 層 7 プライ(CLT 厚さ $210 \mathrm{~mm}$ )の CLT で最も保有水平耐力が高く、鉄骨架構に挿入するには効果的で あるとし設計を進めた。

(3)接合部設計

接合部は CLT の保有水平耐力を最大限発揮するように、接合部耐 力が CLT 保有水平耐力を上回るように設計した。CLT にせん断力 $Q(\mathrm{kN})$ が作用すると、上下の接合部にはそれぞれ水平力が $Q$ だけ働 く。また、それによって CLT パネルが回転する動きによる鉛直力 $V$
$(\mathrm{kN})$ がそれぞれの接合部にはたらき、次の式であらわされる。

$$
V=Q \times \frac{H}{2 W}
$$

$H:$ CLT 高さ $(\mathrm{mm}) 、 W:$ CLT 幅 $(\mathrm{mm})$ である。

四隅の接合部が $V$ に対して十分な耐力を有していること、また上 下それぞれの接合部で $Q$ に対して十分な耐力を有していることを 条件として次の手順として後述する(4)の解析により耐力を把握し たうえで、ドリフトピンの配置については『木質構造設計規準・同 解説』5)に沿って設計した。

(4)ドリフトピン単位接合部の耐力把握

接合部設計に必要となる鋼板扦入ドリフトピン単位接合部の荷重 変位関係を有限要素解析によって求めた。ドリフトピンをはり要素 に、ラミナの支圧を単軸ばね要素とする弾塑性床上のはりモデルを 用いて CLT 強度等級 $(\mathrm{S} 60 / \mathrm{S} 90 / \mathrm{Mx} 60 / \mathrm{Mx} 90) \cdot$ 加力角度 $(0 / \alpha / \beta / \gamma)$ ・ 層プライ数（5層 5 プライ/5 層 7 プライ/7 層 7 プライ）をパラメー タとした。使用するラミナはスギ、厚さ $30 \mathrm{~mm}$ とした。なお、鋼板 が挿入されるためのスリット部分には単軸ばねは設けていない。例 として Fig.1 1 層 5 プライの解析モデル図と、加力角度を示す。 ドリフトピンの中心位置に荷重 $P$ を与えて増分解析を実施し、荷重 $P(\mathrm{kN})$ と加力点の変位 $\delta(\mathrm{mm})$ の関係を求めた。ドリフトピンは完全弾 塑性、降伏強度は $\sigma_{y}=400 \mathrm{~N} / \mathrm{mm}^{2}$ とした。ラミナの支圧強度特性は 次の手順で決定した。

(1)木質構造設計規準 5)より、スギの基準支圧強度は繊維方向を $19.4 \mathrm{~N} / \mathrm{mm}^{2}$ 、繊維直角方向を $9.7 \mathrm{~N} / \mathrm{mm}^{2}$ とした。

(2)ラミナの曲げ強さと支圧強度に相関があると仮定し、M60 のラミ
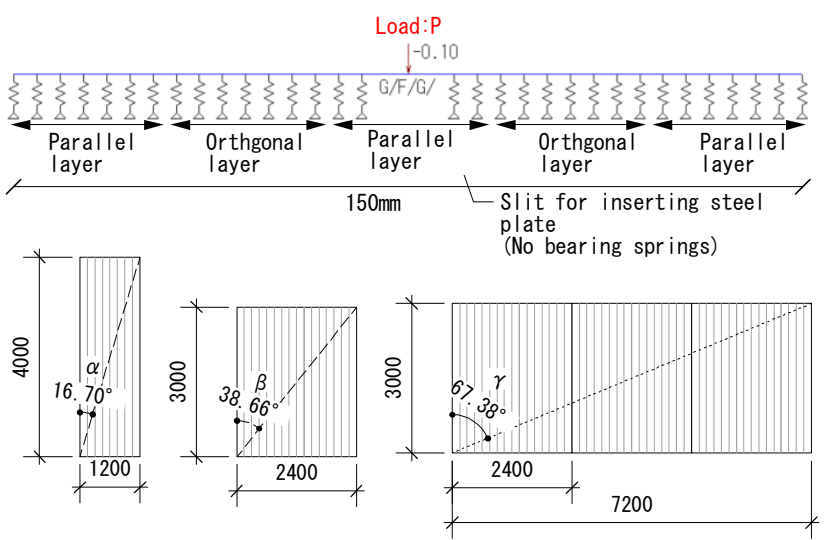

Fig.1 Analysis model and definition of loading angle 
ナ支圧強度が基準支圧強度であるとして、曲げ強さの M60 に対 する比率により M30、M90のラミナ支圧強度を求めた。

(3)既往の実験結果 6)より繊維方向、繊維直角方向の降伏点変位を $1.10 \mathrm{~mm} 、 1.64 \mathrm{~mm}$ として支圧剛性を算出し、二次剛性の初期剛 性に対する比 $p$ をそれぞれ $0.001 、 0.16$ とした。

(4)繊維方向に対する加力角度が $\alpha^{\circ} 、 \beta^{\circ} 、 \gamma^{\circ}$ の時の支圧強度 $F$ と 降伏点変位をハンキンソン式 5)によって求め、支圧剛性 $k$ を算出 した。二次剛性については、 $0^{\circ} 、 90^{\circ}$ のグラフの交点にそれぞれ の角度の第 2 直線が向からように決定した。これらにより求めた 単軸ばねの特性を Table 2 に示す。表中の $F_{0}$ は左欄の角度 $\theta$ 時の 支圧強度を、 $F_{90}$ は角度 $\theta$ の直交方向の支圧強度をあらわす。Fig.2 に Table2 中の M60 のラミナについて、単軸ばねの荷重変形特性 を示す。

解析結果により得た荷重変位関係の一例として S90 に対する 5 層 5 プライ (S90-5-5) と 5 層 7 プライ (S90-5-7)の結果を Fig.3 に示す。 CLT 強度等級、層プライ数に関わらず、加力角度による荷重変位関 係には大きく違いがみられなかった。Table 3 に参考として、加力 角度 $0^{\circ}$ のときの初期剛性 $K$ と降伏点 $P_{y}$ を整理して示した。ここ で、 $P_{\max }$ を変位 $20 \mathrm{~mm}$ 時の荷重とし、初期剛性は $0.1 P_{\text {max }}$ と $0.4 P_{\text {max }}$ を結ぶ直線の傾き、降伏点は初期剛性を求めるために引いた直線を 変位の正方向に $0.4 \mathrm{~mm}$ (終局変位 $20 \mathrm{~mm}$ の $2 \%$ ) 移動させた直線と荷 重変形曲線の交点として求めた。

(5)実験用 $1 / 2$ スケールへの適用

想定モデルは、 5 層 7 プライ (厚さ $210 \mathrm{~mm}$ ) の CLT と径 $\varphi=20 \mathrm{~mm}$ のドリフトピンである。実験は想定するモジュールの $1 / 2$ スケール で行う。前述した通り、CLT パネルとして効率が良いと考えられる のは 5 層 7 プライの壁であった。しかし、5 層 7 プライで厚さが $105 \mathrm{~mm}$ となる CLT は製造不可能であったため、ラミナ厚を $21 \mathrm{~mm}$ とした 5 層 5 プライのパネルを用いざるを得なかった。ただし、 CLT の幅が比較的大きく、高さが低く、せん断と曲げの差が少なく なるように配慮した。また、(4)で用いた解析方法で、実験用のドリ フトピンの性能を求め、実物大と比較検討した。実験は $1 / 2$ スケー ルで CLT の保有水平耐力は $1 / 4$ となるので、実験用のドリフトピン の強度は想定モデルの $1 / 4$ となればよい。Fig.4 に解析結果を示す。 ドリフトピンは径 $\varphi=10 \mathrm{~mm}$ でほぼ一致することが確認できた。

\section{3. 試験計画}

試験体の概略を Fig.5 に示す。試験体は、CLT の有無、CLT の強 度等級、CLT 挿入位置をパラメータとして各 1 体ずつ、全 4 体とし た。基本仕様とした試験体は S60-C1 で、強度等級 S60 の CLT を 鉄骨架構の中央に配置している。F-00 は鉄骨架構のみの試験体、 S90-C1 は CLT の強度等級を S90 とした中央配置の試験体、S60E1 は CLT を端に配置した試験体とした(Fig.7 参照)。

鉄骨架構の寸法は共通であり、柱心間距離 $3600 \mathrm{~mm}$ 、はり心間距 離 $2000 \mathrm{~mm}$ であり、柱には SN490B の RH-300×300×10×15、は りには SN400B の RH- $294 \times 200 \times 8 \times 12$ を使用した。それぞれの 試験体の CLT 耐震壁挿入位置に適宜補強用のリブを設けた。柱と はりは溶接とし、柱下部の下はり・柱中心軸上にピンを設けた。鉄 骨と CLT は鋼板挿入ドリフトピン接合で、径 $\varphi=10$ 、長さ $l=105 \mathrm{~mm}$ のドリフトピンを四隅に各 32 本とせん断力伝達用のドリフトピン
Table 2 Characteristics of springs for embedment

\begin{tabular}{|c|c|c|c|c|c|c|c|}
\hline \multicolumn{2}{|c|}{ Angle to the fiber direction } & \multicolumn{3}{|c|}{$\theta^{\circ}$} & \multicolumn{3}{|c|}{$90-\theta^{\circ}$} \\
\hline \multirow{2}{*}{$\begin{array}{l}\text { Lamina } \\
\text { strength }\end{array}$} & \multirow{2}{*}{$\theta$} & $F_{0}$ & $k_{0}$ & $p_{0}$ & $F_{90}$ & $k_{90}$ & $p_{90}$ \\
\hline & & {$\left[\mathrm{N} / \mathrm{mm}^{2}\right]$} & {$\left[\mathrm{N} / \mathrm{mm}^{3}\right]$} & & {$\left[\mathrm{N} / \mathrm{mm}^{2}\right]$} & {$\left[\mathrm{N} / \mathrm{mm}^{3}\right]$} & \\
\hline \multirow{4}{*}{ M30 } & 0 & 14.49 & 13.17 & 0.001 & 7.24 & 4.42 & 0.160 \\
\hline & $\alpha$ & 13.38 & 11.83 & 0.006 & 7.55 & 4.79 & 0.089 \\
\hline & $\beta$ & 10.42 & 8.25 & 0.030 & 9.00 & 6.54 & 0.051 \\
\hline & $\gamma$ & 7.82 & 5.12 & 0.080 & 12.62 & 10.91 & 0.010 \\
\hline \multirow{4}{*}{ M60 } & 0 & 19.40 & 17.64 & 0.001 & 9.70 & 5.91 & 0.160 \\
\hline & $\alpha$ & 17.92 & 15.85 & 0.006 & 10.12 & 6.42 & 0.089 \\
\hline & $\beta$ & 13.95 & 11.06 & 0.030 & 12.05 & 8.76 & 0.051 \\
\hline & $\gamma$ & 10.47 & 6.85 & 0.080 & 16.90 & 14.62 & 0.010 \\
\hline \multirow{4}{*}{ M90 } & 0 & 24.31 & 22.10 & 0.001 & 12.16 & 7.41 & 0.160 \\
\hline & $\alpha$ & 22.46 & 19.86 & 0.006 & 12.68 & 8.05 & 0.089 \\
\hline & $\beta$ & 17.49 & 13.86 & 0.030 & 15.10 & 10.97 & 0.051 \\
\hline & $\gamma$ & 13.13 & 8.59 & 0.080 & 21.18 & 18.32 & 0.010 \\
\hline
\end{tabular}

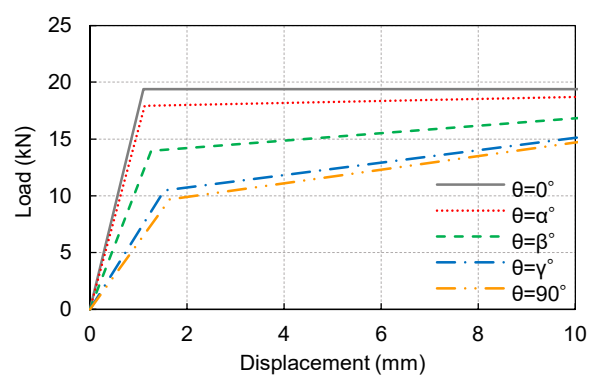

Fig.2 Load-Displacement relationships of bearing springs when lamina strength is M 30
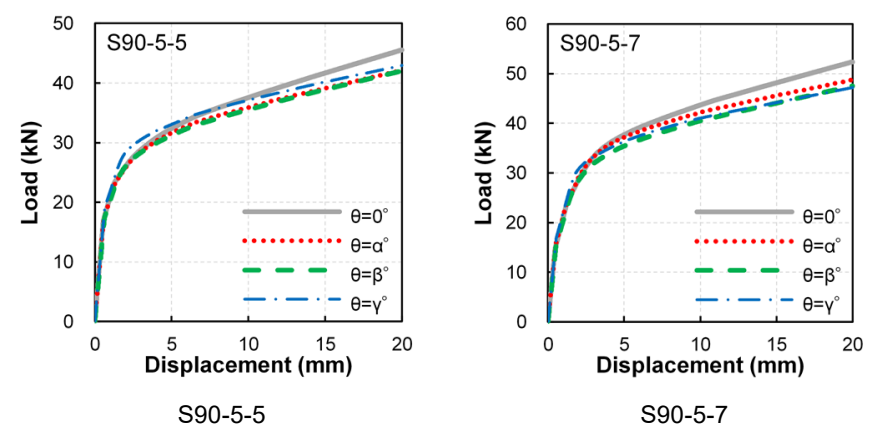

Fig.3 Results of analysis for unit of drift-pin joint

Table3 Results of drift-pin joint analysis

\begin{tabular}{|c|c|c|c|c|c|c|c|c|}
\hline Strength grade & \multicolumn{2}{|c|}{ S60 } & \multicolumn{2}{|c|}{ s90 } & \multicolumn{2}{|c|}{ Mx60 } & \multicolumn{2}{|c|}{ M×90 } \\
\hline \multirow{2}{*}{ Layer-ply type } & K & $P_{y}$ & K & $P_{y}$ & K & $P_{y}$ & K & $P_{y}$ \\
\hline & {$[\mathrm{kN} / \mathrm{mm}]$} & {$[\mathrm{kN}]$} & {$[\mathrm{kN} / \mathrm{mm}]$} & {$[\mathrm{kN}]$} & {$[\mathrm{kN} / \mathrm{mm}]$} & {$[\mathrm{kN}]$} & {$[\mathrm{kN} / \mathrm{mm}]$} & {$[\mathrm{kN}]$} \\
\hline 5layers-5plies & 25.84 & 20.42 & 25.37 & 23.52 & 22.65 & 18.10 & 24.94 & 17.67 \\
\hline 5layers-7plies & 19.69 & 23.04 & 20.80 & 27.29 & 18.76 & 19.55 & 18.00 & 20.93 \\
\hline 7layers-7plies & 24.16 & 25.26 & 24.88 & 31.50 & 23.66 & 19.29 & 22.95 & 19.64 \\
\hline
\end{tabular}

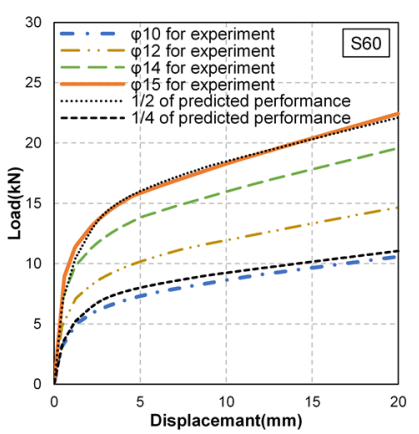

560

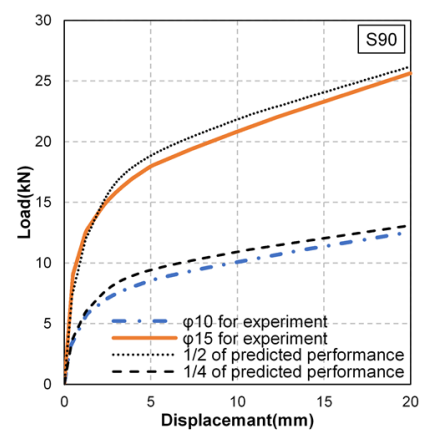

S90
Fig.4 Comparison of full scale to $1 / 2$ scale of drift-pin joint 


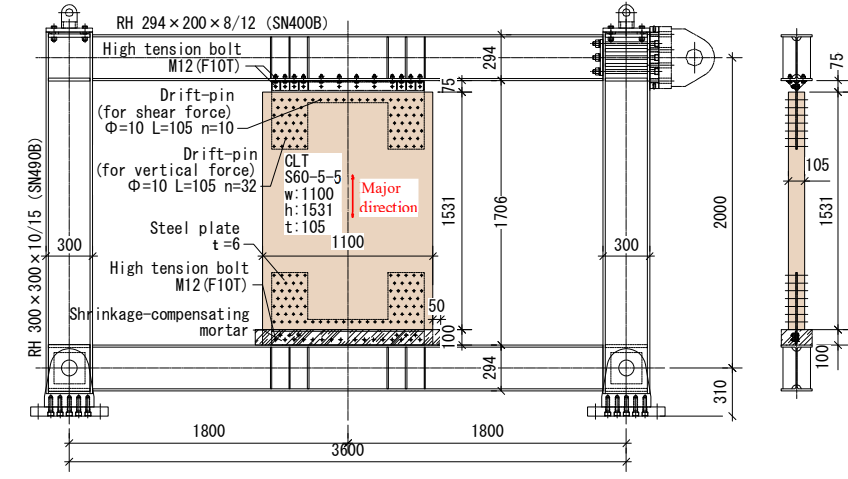

(a) Elevation (S60-C1)

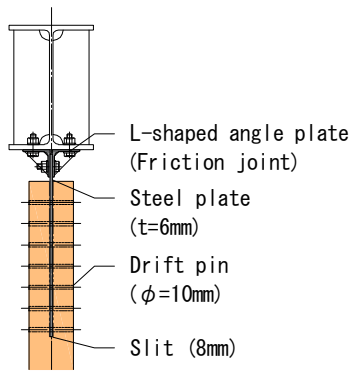

(b) Upper Joint Detail

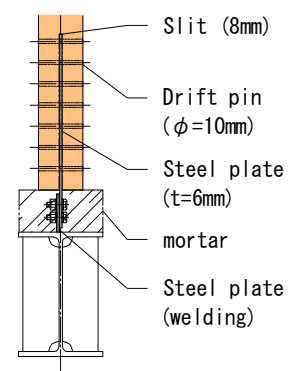

(c) Lower Joint Detail

Fig.5 Specimen

として中央に上下各 10 本で留め付けている。接合部で CLT に挿入 する鋼板の厚さは $6 \mathrm{~mm}$ である。鋼板と上部鉄骨は L 型冶具を前後 から挟み込んで高力ボルトで留め付けている。鋼板と下部鉄骨はり

は、下部鉄骨はりにあらかじめ溶接した鋼板と高力ボルトで留め付 け、さらに鉄骨から CLT の下端まで無収縮モルタルを充填した。

使用した CLT は、前述の通りラミナ厚が $21 \mathrm{~mm} の 5$ 層 5 プライ であり、高さは $1531 \mathrm{~mm}$ 、幅は鉄骨架構の内法の $1 / 3$ である $1100 \mathrm{~mm}$ である。S60-E1 についてはおさまりの都合上、幅が 1075mm とな った。CLT や鋼材などの基本的な特性については「5.1 用いた材 料の強度特性の把握と要素モデルの定義」にて説明する。

Fig.6 には 5 章に後述する解析モデルを用いて、事前に荷重変形 関係を予測した結果を示した。なお、鋼材強度は $F$ 值の 1.1 倍とし て、降伏後の剛性低下率を 0.001 とモデル化した。CLT の特性值は CLT 設計施工マニュアル4) を参考にTable4のようにモデル化した。 支圧バネは CLT のヤング係数と強度より完全弾塑性とモデル化し た。CLT の耐力が基準強度に比較して安全側に設計されていること と、鉄骨はりの塑性化に対して必要な CLT の耐力を確認する目的 で、CLT は曲げ耐力、せん断耐力に達した後も非線形化しないもの として計算を進めた。ドリフトピン接合部は 2 章で述べた単体の荷 重変形関係を本数倍してトリリニアでモデル化した。S60-E1 は方 向性があると考えられるので、正負で増分解析を実施した。

S60-C1 は CLT の曲げ耐力にまず達し、その後鉄骨はりが降伏す る。一方で、等級が S90 となると CLT の曲げ耐力は鉄骨はりの降 伏とほぼ同時となる。S60-E1 は正負の違いはみられず、鉄骨はりの 降伏の後、CLT の曲げ耐力に至っている。

加力装置を Fig.7 に示す。試験体の右側柱頭部分に加力ジャッキ を取り付け、引き側を正、押し側を負として正負交番の 3 回繰り返 し加力とした。加力スケジュールは、上はり軸心位置の水平変形を 上下のはりの軸心間高さ $2000 \mathrm{~mm}$ で除して求まる制御変形角 $R$ で

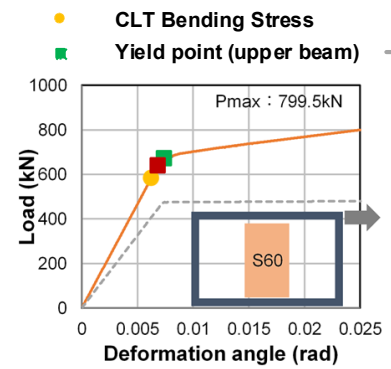

(1) $\mathrm{S} 60-\mathrm{C} 1$

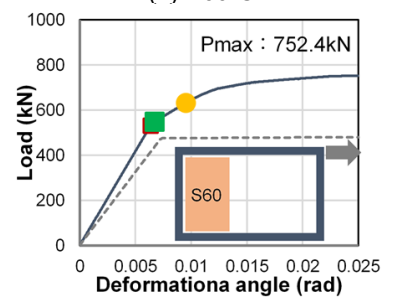

(3) S60-E1(Positive load)
- Yield point (lower beam) Result of frame analysis

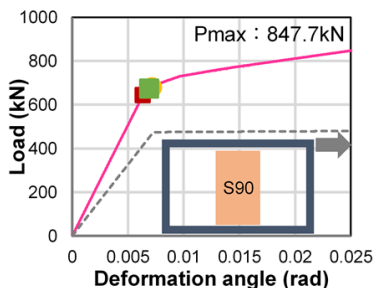

(2) S90-C1

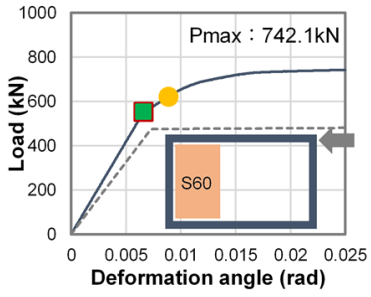

(4) S60-E1(Negative load)

Fig.6 Pre-analysis result

Table4 Material properties of analysis model of CLT

\begin{tabular}{llr}
\hline Modulus of elasticity (S60) & $\mathrm{N} / \mathrm{mm}^{2}$ & 3,600 \\
Modulus of elasticity (S90) & $\mathrm{N} / \mathrm{mm}^{2}$ & 5,400 \\
Shear modulus (S60/S90) & $\mathrm{N} / \mathrm{mm}^{2}$ & 500 \\
\hline
\end{tabular}

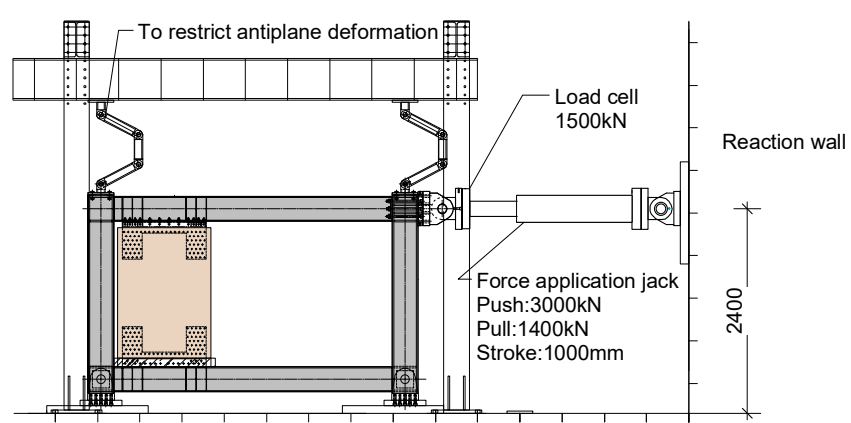

Fig.7 Loading setup

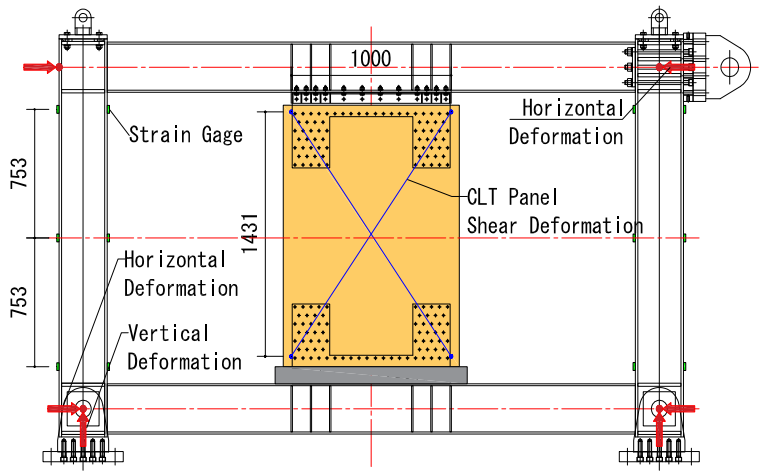

Fig.8 Measurement

$1 / 450 、 1 / 300 、 1 / 200 、 1 / 150 、 1 / 100 、 1 / 75 、 1 / 50 、 1 / 30 \mathrm{rad}$ 、その後 1/10rad を目安に一方向載荷とした。

計測計画を Fig.8 に示す。変位について、上下柱はり接合部中央 の裏表で水平変位を、CLT パネルの対角でパネルせん断変位を測定 した。さらに、柱が負担する水平力を把握するため、柱の両側の上 部・中央部・下部に歪ゲージを貼付した。 


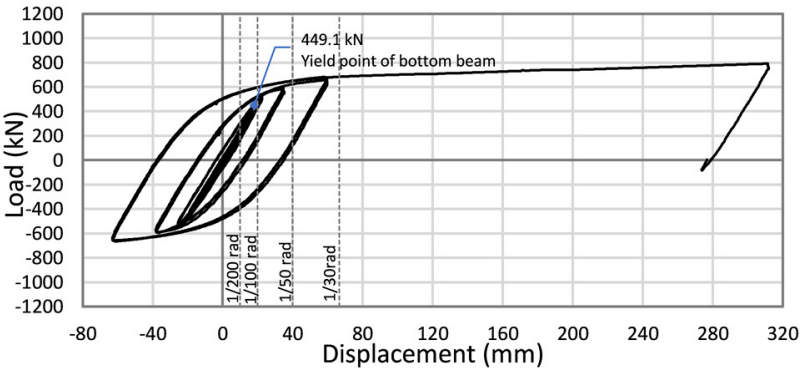

(1) $\mathrm{F}-00$

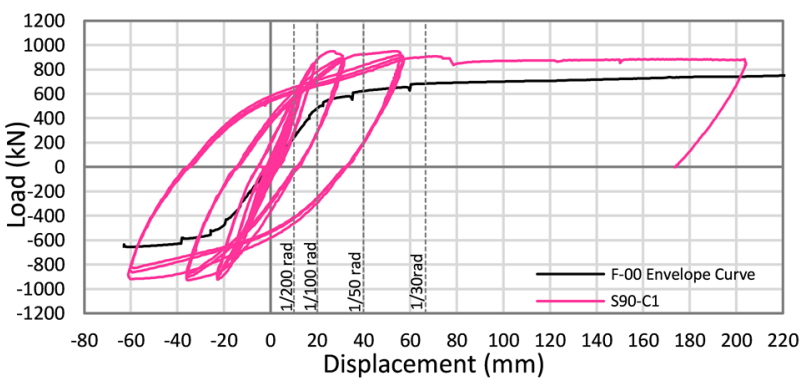

(3) S90-C1

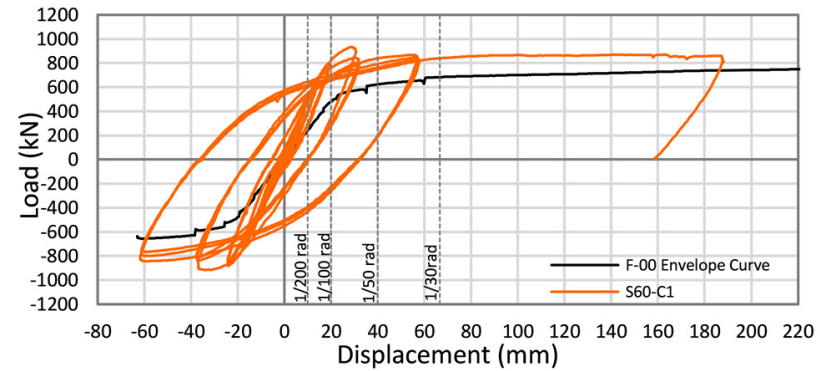

(2) S60-C1

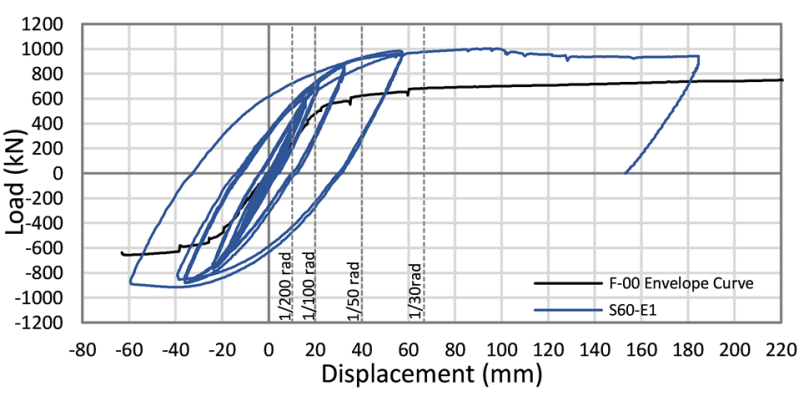

(4) S60-E1

Fig.9 Results of experiment

\section{4. 実験結果}

Fig.9 に水平荷重-層間変形関係を示す。ここで、層間変形は上部 のはり軸心の水平変形から試験体下部の水平変位を引いた值である。 図中には目標としていた制御变形角 $R$ となる変位を破線で示してい るが、実際の層間変形は試験体下部の水平変位の影響で目標として いた変形角に達していないことに注意されたい。

いずれの試験体も制御変形角 $R=1 / 50 \mathrm{rad}$ から同 $1 / 30 \mathrm{rad}$ に向かう 繰り返しで多少の荷重の低下がみられるが、制御变形角 $R=1 / 30 \mathrm{rad}$ 時までの繰り返しでは、スリップ的な挙動はみられず、鉄骨造の荷 重変形に近い。破壊性状について述べると、試験体 F-00 は、制御変 形角 $R=1 / 75 \mathrm{rad}$ の正側 1 回目に下はり端部の歪が塑性化レベル に達した。 $R=1 / 50 \mathrm{rad} の$ 正側で下はりの局部座屈を観察した。 $R=1 / 30 \mathrm{rad}$ まで各 3 回正負交番繰り返したのち引き壊した。耐力低 下は見られず、柱の端部の変形が見られたため全体変形 $\delta=300 \mathrm{~mm}$ で試験を終了した。F-00 の $R=1 / 6.6 \mathrm{rad}$ 加力時の全体の様子を Photo1(a)に示す。

S60-C1 と S90-C1 の破壊性状には大きな違いはなく、制御変形角 $R=1 / 150 \mathrm{rad}$ の加力サイクルにて脚部モルタルの割れが生じ始め、 その後サイクルが増えるごとに割れが広がった。 $R=1 / 100 \mathrm{rad} の$ 加 カサイクルで CLT の亀裂音が発生した。次いで、 $R=1 / 50 \mathrm{rad}$ の加 カサイクルで CLT の表層ラミナが鉛直方向にずれてせん断破壊す る様子が顕著となり（Photo1(b))、2 サイクル目からは 1 サイクル 目の最大荷重に届かなかった。 $R=1 / 30 \mathrm{rad}$ の加力サイクルで鉄骨は りの柱との接続部付近で目視によっても降伏が見られ、荷重が上昇 しなくなった。また、ドリフトピン接合部の引張力を受ける箇所で は CLT のスリットが開く様子が観察された。その後、R=1/10 $\mathrm{rad}$ まで引き壊した。その間に圧縮力を受ける接合部ではモルタルの圧 壊と CLT の圧壊 $(\operatorname{Photo1}(\mathrm{c})$ )、挿入鋼板の座屈、それに伴う CLT スリットの開き $(\operatorname{Photo1}(\mathrm{d}))$ が観察され、引張を受ける接合部では、 挿入鋼板の破断 $(\operatorname{Photo1}(\mathrm{e}))$ が観察された。
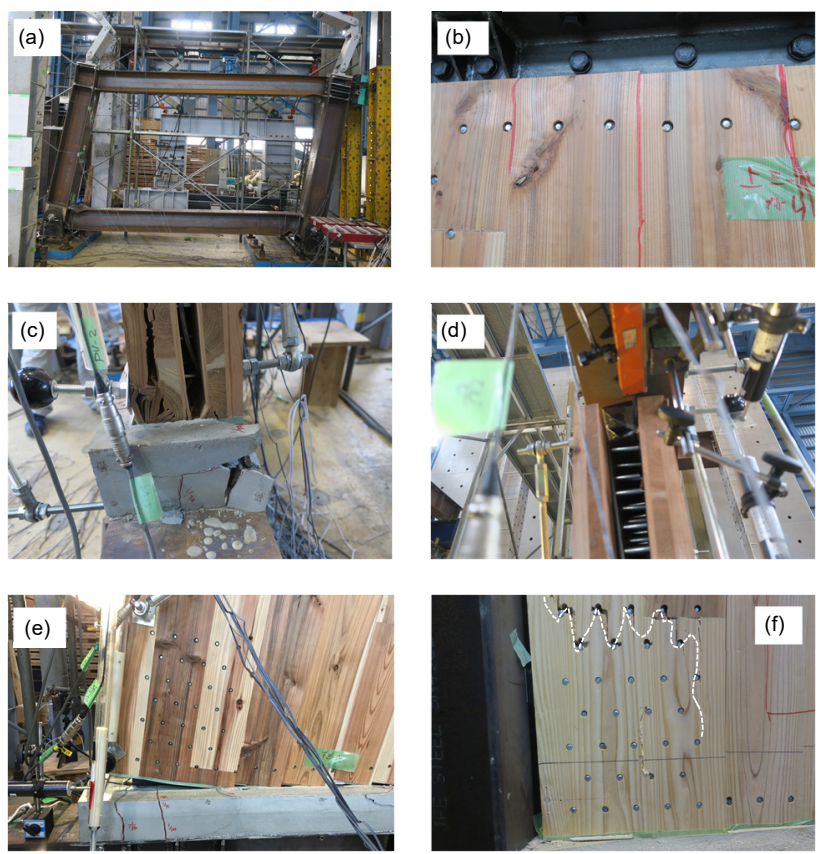

Photo1 Destruction property

$\mathrm{S} 60-\mathrm{E} 1$ 試験体は、制御変形角 $R=1 / 100 \mathrm{rad}$ の加力サイクルにて 脚部モルタルの割れが生じ初め、その後サイクルが増えるごとに割 れが広がった。同サイクルで、CLT の破壊音が発生したのは他と同 様である。 $R=1 / 75 \mathrm{rad}$ で鉄骨下はりの端部の降伏を確認した。また、 下部引張側のモルタル端部が浮き上がっていることと、上部の挿入 鋼板と摩擦接合している L 型金物の間に滑りが生じていることを 確認した。次いで、 $R=1 / 50 \mathrm{rad}$ の加力サイクルで CLT の表層ラミ ナがずれてせん断破壊する様子が顕著となった。 $R=1 / 30 \mathrm{rad} の$ 負側 1 回目で鉄骨上部の局部座屈と面外一の横座屈による面外変形がみ られたため、2 回目のサイクルは、正側を $R=1 / 30 \mathrm{rad}$ まで、負側は $R=1 / 50 \mathrm{rad}$ までとし、3 回目のサイクルをとりやめた。その後 


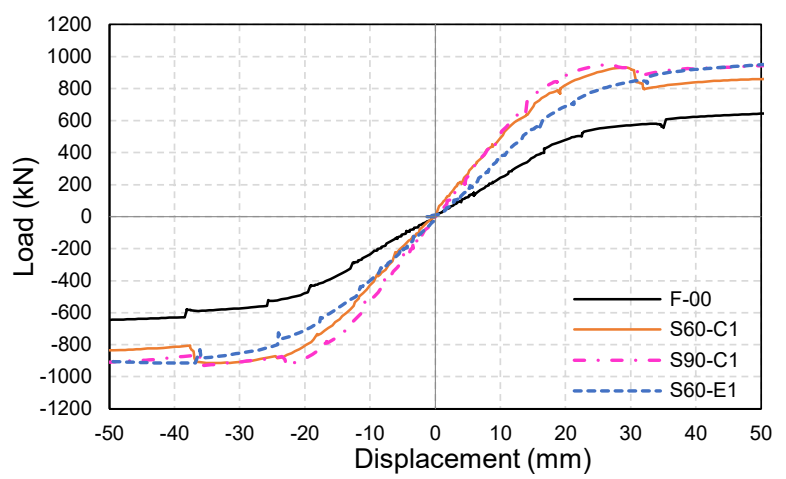

Fig.10 Envelope curves of experiment

$R=1 / 10 \mathrm{rad}$ まで正側に一方向載荷を行った。その間、CLT のドリフ トピン接合部が集合型引張破断し(Photo1(f)) 荷重低下がみられた。 そのほかの破壊状況は同様であり、鉄骨下はりの局部座屈、CLT の 局部圧壊、モルタルの圧壊も観察された。

荷重変位関係の包絡線をそれぞれの試験体を比較して、Fig.10に 示す。また、最大荷重、初期剛性などの定量的な比較をし Table 5に 示す。初期剛性は最大荷重 $P_{\text {max }}$ の 0.1 倍、0.4 倍の荷重とその時の 変形を結ぶ直線の傾きとした。結果は以下のように要約できる。

1) CLTを 1 枚挿入することによって正側では最大荷重はおよそ 1.2 〜 1.3 倍、負側ではおよそ 1.4 倍、初期剛性は 1.5 2.3 倍となり、 耐力上昇効果が十分にあることが確認できた。

2) CLT の強度等級が S60 から S90 になると、初期剛性は上がった が、最大荷重の上昇はわずかであった。破壊性状や挙動に大きな 差は見られなかった。

3) CLT の挿入位置を端とした S60-E1 では、初期剛性は小さくなっ た。また、CLT の破壊が起こる前に鉄骨架構の座屈が見られ、そ の後ドリフトピン接合部が破壊し、破壊性状に大きく違いが見ら れた。

次に、CLT の負担せん断応力とせん断変形角関係の包絡線を

Fig. 11 に示す。CLT の負担せん断応力は、計測荷重から歪ゲージ計 測值より算出した鉄骨柱の負担せん断力を差し引いて、これをCLT の実断面積で除することで算出した。せん断変形角は、鋼板挿入部 を含む CLT パネルのせん断変形を計測し、その計測高さで除する ことで算出した。CLT の耐力については以下のように要約できる。 なお、図中のせん断弾性係数は後述の CLT の材料実験で得られた 值である。

4）全ての試験体で、CLT の面内せん断基準強度 $2.7 \mathrm{~N} / \mathrm{mm}^{2}$ 以上 の耐力が得られた。

5) CLT を中央に配置した試験体（S60-C1、S90-C1）では CLT の せん断変形角が $0.01 \mathrm{rad}$ 付近のときせん断破壊が生じ、多少の 応力低下が見られた。

6) CLT の強度等級が S60 のものと S90 のものでは、 S90 の剛 性が高いことが確認でき、後述する要素試験におけるせん断弾性 係数の比率と同程度となった。

7）CLT を端に配置した試験体（S60-E1）では集合型破壊したにも かかわらず、せん断破壊が起こらないためか、大きな応力低下は 見られなかった。
Table5 Test results

\begin{tabular}{|c|c|c|c|c|c|c|}
\hline & & & $F-00$ & $\mathrm{~S} 60-\mathrm{C1}$ & $\mathrm{S} 90-\mathrm{C} 1$ & S60-E1 \\
\hline \multirow{4}{*}{ Positive } & Maximum load: $P_{\max }$ & {$[\mathrm{kN}]$} & 791.3 & 931.7 & 950.4 & 1003.4 \\
\hline & Ratio to $\mathrm{F}-00\left(\mathrm{P}_{\max }\right)$ & & & 1. 18 & 1. 20 & 1. 27 \\
\hline & Initial stiffness:K & {$[\mathrm{kN} / \mathrm{mm}]$} & 24. 32 & 46.08 & 51.88 & 37.11 \\
\hline & Ratio to $\mathrm{F}-00(\mathrm{~K})$ & & & 1.89 & 2. 13 & 1.53 \\
\hline \multirow{4}{*}{ Negative } & Maximum load: $P_{\max }$ & {$[\mathrm{kN}]$} & -664.7 & -915.1 & -928.9 & -915.3 \\
\hline & Ratio to $\mathrm{F}-00\left(\mathrm{P}_{\max }\right)$ & & & 1.38 & 1. 40 & 1.38 \\
\hline & Initial stiffness:K & {$[\mathrm{kN} / \mathrm{mm}]$} & -23.70 & -45.15 & -54.33 & -38.31 \\
\hline & Ratio to F-00(K) & & & 1.91 & 2. 29 & 1.62 \\
\hline
\end{tabular}

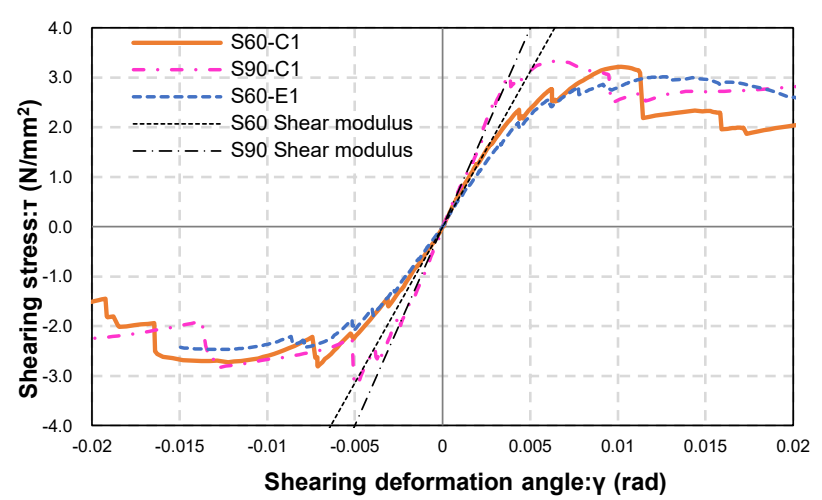

Fig.11 Envelope curves of shearing stress-deformation angle

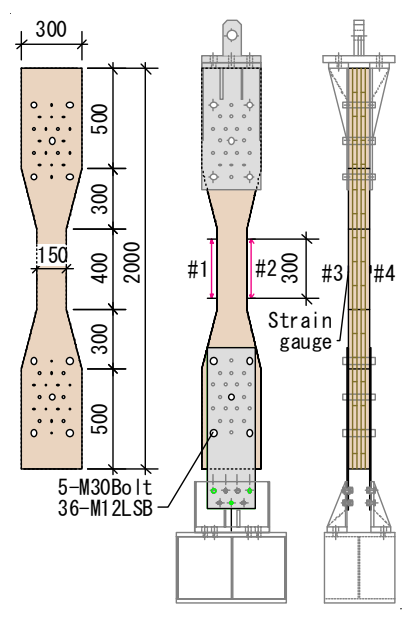

(a) CLT tensile test
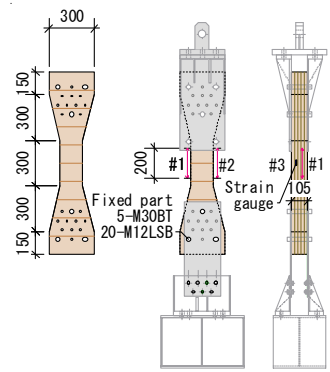

(b) CLT tensile test

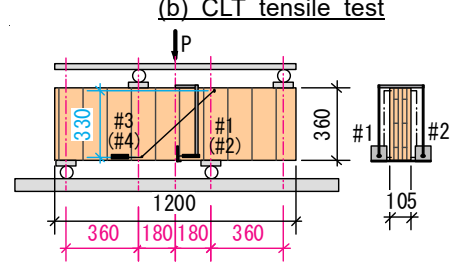

(c) CLT shear test

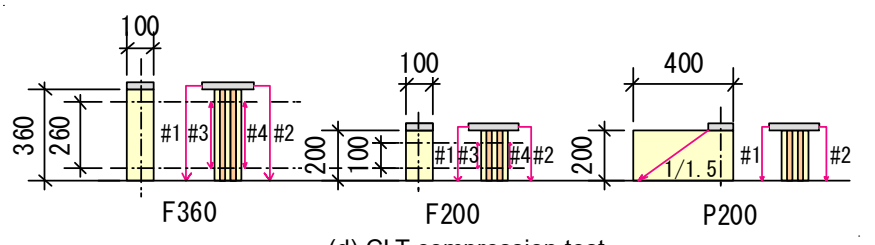

(d) CLT compression test

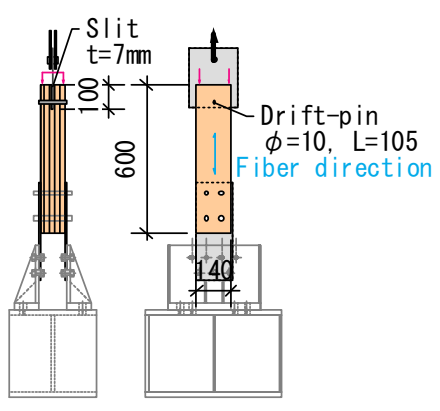

(e) Unit joint tensile test

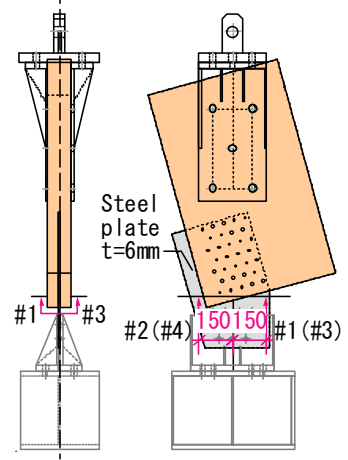

(f) Joint tensile test

Fig.12 Specimen of material tests 


\section{5. 解析による実験結果の追跡}

\section{1 用いた材料の強度特性の把握と要素モデルの定義}

構面実験で用いた CLT、鉄骨、ドリフトピン、モルタルの材料特 性と接合部の性能を確認するために要素試験を行った。また、これ らの要素実験の結果を用いて、次項で解析的に実験結果の追跡を試 みた。なお、CLT については引張試験、せん断試験、圧縮試験を、 鋼材については引張試験を、ドリフトピンについては引張試験、3 点 曲げ試験を、無収縮モルタルについては圧縮実験を実施した。接合 部については単位接合部引張試験、構面実験で使用したドリフトピ ン本数と同じ 32 本の接合部全体引張試験を実施した。これらの試 験体は、構面実験と同時期に発注し、一部の試験体は同じマザーボ ードから製作している。Fig.12 の(a)に CLT 強軸引張試験、(b)に CLT 弱軸引張試験、(c)に CLT せん断試験、(d)に CLT 圧縮試験、 (e)に単位接合部引張試験、(f)に接合部全体引張試験の試験体図を示

す。Fig.12 各図において計測位置を\#1,\#2のように示す。

CLT の強軸引張試験の結果を Fig.13 に示す。Fig.13 横軸の歪 $\varepsilon$ は、計測位置での変位を標点距離で除して求めた。強度等級 S60、 S90 について、強軸方向と弱軸方向の試験体を各 4 体製作し、試験 に供した。強軸方向のヤング係数は $\mathrm{S} 60$ が $6005 \mathrm{~N} / \mathrm{mm}^{2} 、 \mathrm{~S} 90$ が $5919 \mathrm{~N} / \mathrm{mm}^{2}$ となり、弱軸方向は $\mathrm{S} 60$ が $3866 \mathrm{~N} / \mathrm{mm}^{2} 、 \mathrm{~S} 90$ が $3813 \mathrm{~N} / \mathrm{mm}^{2}$ となった。 $\mathrm{S} 60$ が強くなったが、その理由としては、 $\mathrm{S} 60$ の節が少なく、さらに、試験体中にフィンガージョイントがな かったこと、などが考えられる。

せん断試験の結果を Fig.14 に示す。Fig.14のせん断歪 $\gamma$ は、試験 体裏表の中央で計測した水平変位 $(\mathrm{Fig} .12(\mathrm{c})$ 中の\#1,\#2)の平均值を はりせい $360 \mathrm{~mm}$ で除して求めた。せん断試験は S60、S90 それぞ れ 6 体ずつ試験に供した。実験結果より得られたせん断弾性係数は $\mathrm{S} 60$ が $627 \mathrm{~N} / \mathrm{mm}^{2} 、 \mathrm{~S} 90$ が $798 \mathrm{~N} / \mathrm{mm}^{2}$ であった。

CLT の圧縮実験は、全面圧縮試験体として高さが $360 \mathrm{~mm}$ の F360、 $200 \mathrm{~mm}$ の F200の 2 種類の試験を実施した。実験では部分圧縮の 挙動がみられたことより、圧縮面積を同じとしたまま、試験体の幅 が大きい部分圧縮試験 P200 も同様に用意し、加力実験に供した。 全面圧縮では全体の圧縮変位の他に標点間距離の圧縮変位を計測し、 前者を見かけの圧縮変位、後者を真の圧縮変位とした。F200の真の 圧縮変位から算出した圧縮ヤング係数は $\mathrm{S} 60$ が $5601 \mathrm{~N} / \mathrm{mm}^{2} 、 \mathrm{~S} 90$ が $7034 \mathrm{~N} / \mathrm{mm}^{2}$ であった。圧縮強度は $\mathrm{S} 60$ が $25.33 \mathrm{~N} / \mathrm{mm}^{2} 、 \mathrm{~S} 90$ が $29.14 \mathrm{~N} / \mathrm{mm}^{2}$ であった。

単位接合部試験は引張加力方向を繊維方向、繊維直交方向、斜め 方向の 3 種類として 60 、S90 それぞれについて単調引張試験を実 施した。ここで、斜め方向とは構面実験の各接合部が負担する水平 力と鈆直力の合力方向である。加力方向による大きな違いは見られ なかった。また、2 章で述べた解析結果と比較すると、1 次剛性は 一致しているものの、降伏点や最大荷重は解析が実験の半分程度で あった。この要因はドリフトピンや CLT の材料強度が基準強度よ り高い性能を有していたことがあげられる。

全体接合部試験では、加力方向を斜め方向として、降伏点付近で 1 回繰り返し載荷のち単調引張とした。S60、S90 それぞれ 4 体を 試験に供したが、降伏点に至る一次剛性について、強度等級による 違いは見られなかった。
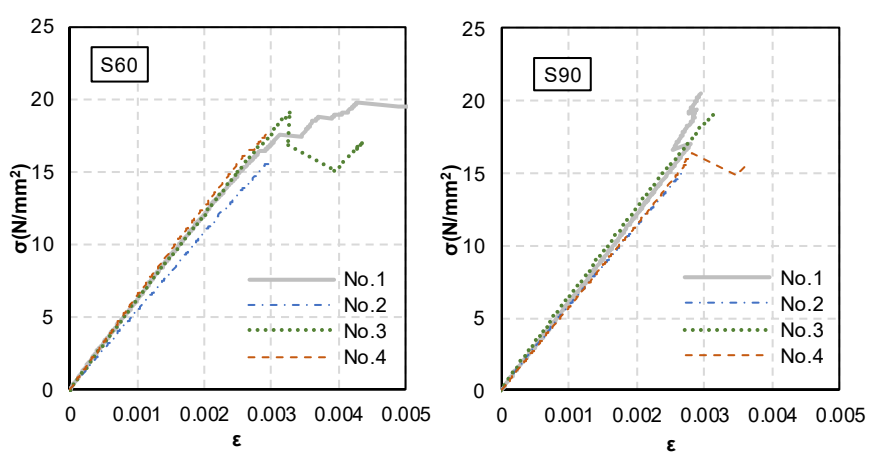

Fig. 13 Results of CLT tensile test
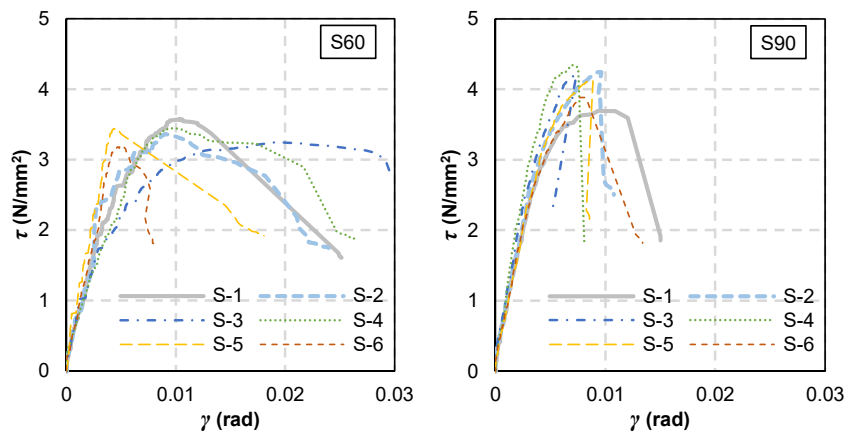

Fig.14 Results of CLT shear test

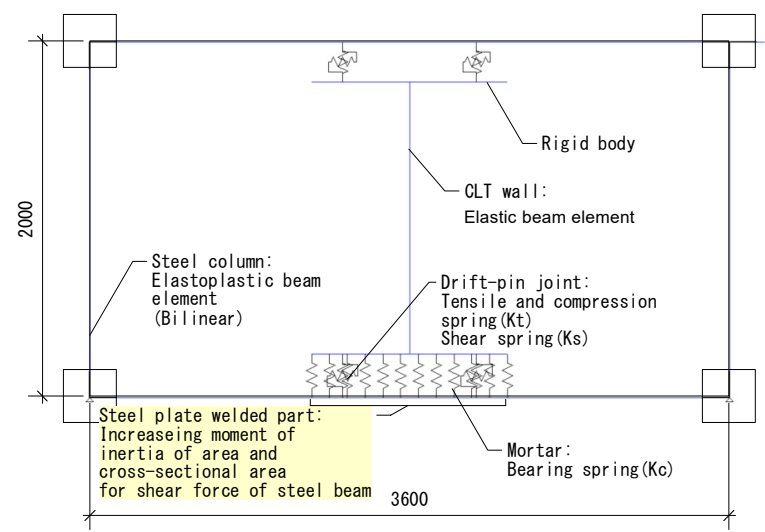

Fig.15 Analysis model

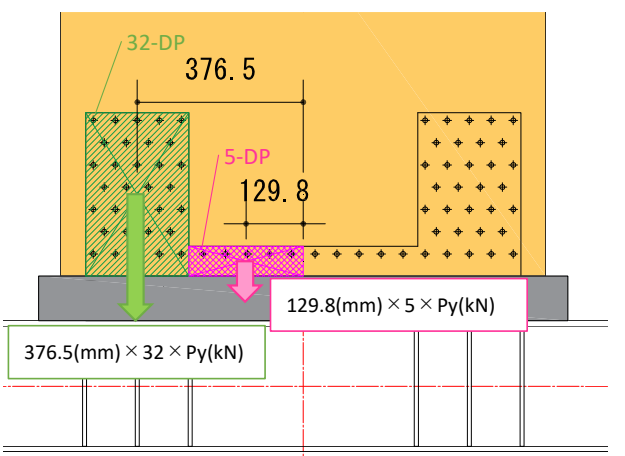

Fig.16 Calculation of bending moment borne by DP joint

\section{2 解析による実験結果の追跡}

要素実験の結果を用いて構面実験を再現する有限要素解析モデル を作成し、実験結果との整合性を確認した。解析は汎用ソフト SNAP ver.7 を用いた。Fig.15 は解析モデルの模式図である。柱はりを線 材弾塑性要素、CLT を壁幅と等しい長さの剛体にはさまれた弾性線 
材要素とし、接合部にドリフトピン接合を模した圧縮・引張バネと せん断バネを上下 2 か所に配置している。さらに、CLT と下はりの 間には無収縮モルタルによって、圧縮抵抗することを考慮し、支圧 バネ要素を設けた。CLT 材料特性は要素実験で得られた值を用いた。 ドリフトピンについては、Fig.16で示寸鋼板の外側の斜線部のみを 鉛直力を負担するドリフトピンとし、そのバネ特性は全体接合部試 験の結果を用いて Table6 の值でトリリニアにモデル化した。Fig.16 に外側斜線部のドリフトピンと中央部のドリフトピンがそれぞれ負 担する鉛直方向のモーメントを示す。その合計に対して、中央部が 負担するモーメントの割合はおよそ $5 \%$ であり、省略しても大きく 影響しないと判断した。また、鉄骨柱はりの材料特性は、鋼材の引 張試験の降伏点でバイリニアにモデル化した。CLT と鉄骨はりが接 合されている部分は実験において鋼板が溶接されているため該当部 分の断面 2 次モーメントとせん断用面積を割増した。支圧バネにつ いては、CLT の部分圧縮実験では全面圧縮に比べてヤング係数が大 きくなる傾向にあることが報告されており7)、材料実験で得られた ヤング係数の 1.1 倍を用いてバネ特性を決定し、剛性 $T_{c}$ と降伏耐力 $F_{y}$ を以下のようにもとめ、バイリニアとした。

$$
\begin{gathered}
T_{c}=\frac{E_{c} \times 1.1 \times t \times d}{h} \\
F_{y}=F_{c} \times t \times d
\end{gathered}
$$

ここで、 $E_{c}$ : 前述した要素試験 F200の CLT 圧縮ヤング係数、 $t$ : CLT 厚さ $(105 \mathrm{~mm}) 、 d:$ ばね間隔 $(100 \mathrm{~mm}) 、 h:$ 支圧作用高さ $(\mathrm{CLT}$ 圧縮試験区間長さ $200 \mathrm{~mm}$ )、 $F_{c}$ : 要素試験の CLT 圧縮強度である。
Table6 Joint model property

\begin{tabular}{ccccc}
\hline Symbol* & Explanations & & S60 & S90 \\
\hline \hline Fc & Yield load from joint test & {$[\mathrm{kN}]$} & 311.43 & 355.77 \\
$\mathrm{~d}(\mathrm{Fc})$ & Displacement of yield load & {$[\mathrm{mm}]$} & 2.610 & 3.060 \\
$\mathrm{~K}$ & Initial stiffness & {$[\mathrm{kN} / \mathrm{mm}]$} & 119.32 & 116.26 \\
$\mathrm{Fy}$ & Maximum load from joint test & {$[\mathrm{kN}]$} & 418.88 & 468.22 \\
$\mathrm{~d}(\mathrm{Fy})$ & Displacement of maximum load & {$[\mathrm{mm}]$} & 10.250 & 17.550 \\
$\mathrm{~K}^{\prime}$ & Secondary stiffness & {$[\mathrm{kN} / \mathrm{mm}]$} & 14.064 & 7.761 \\
$\alpha$ & Ratio of K to K' & - & 0.118 & 0.067 \\
$\beta$ & Ration of third stiffness to K' & - & 0.001 & 0.001 \\
\hline
\end{tabular}

${ }^{*}$ These symbols refer to right figure

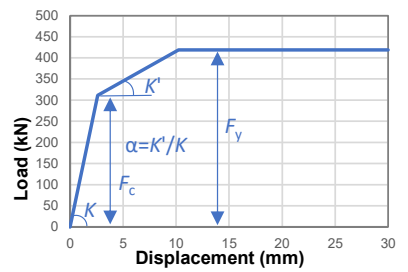

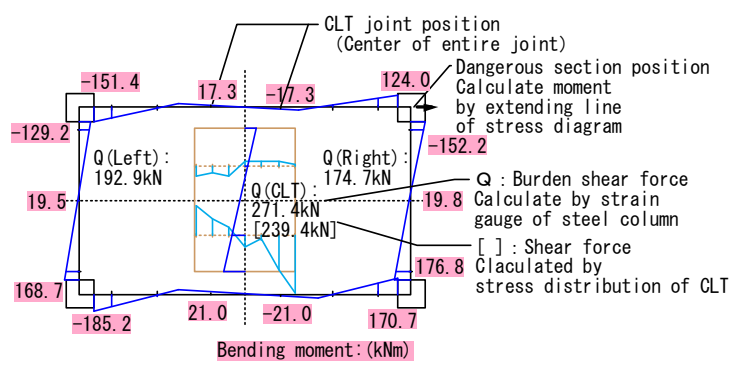

Fig.17 Figure Legend (Fig.19)
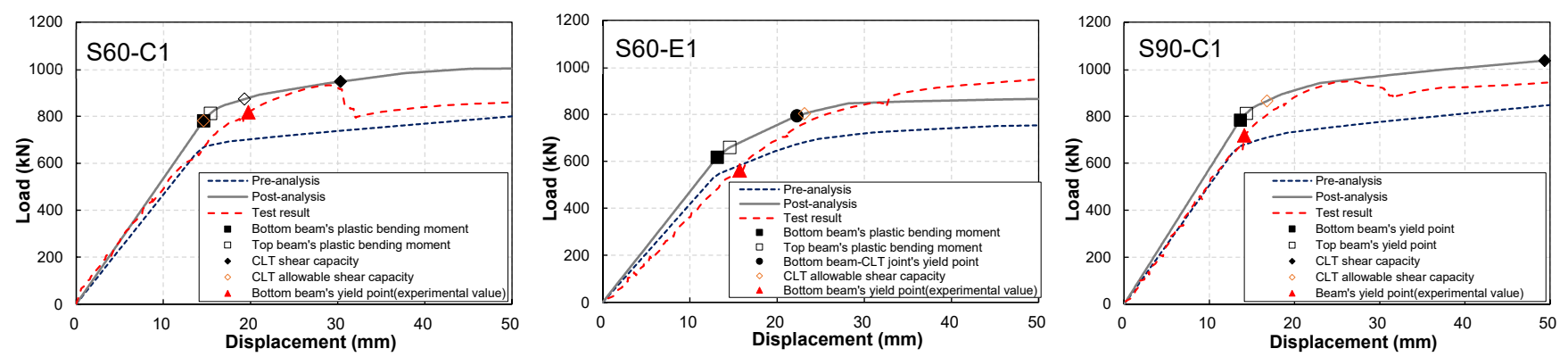

Fig.18 Comparison of test and analysis results

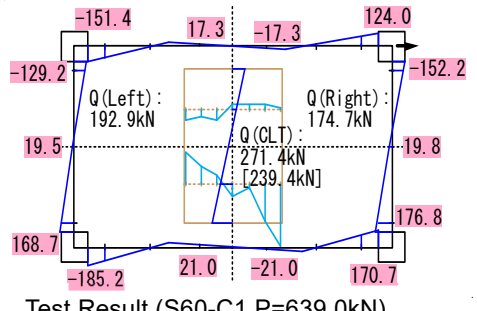

Test Result (S60-C1 P=639.0kN)

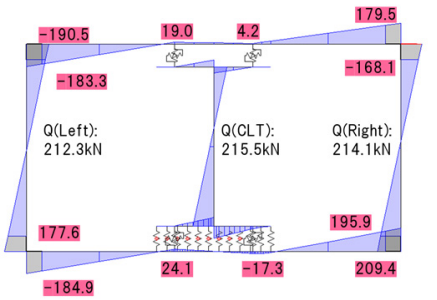

Analysis Result ( $660-\mathrm{C} 1 \mathrm{P}=641.9 \mathrm{kN})$

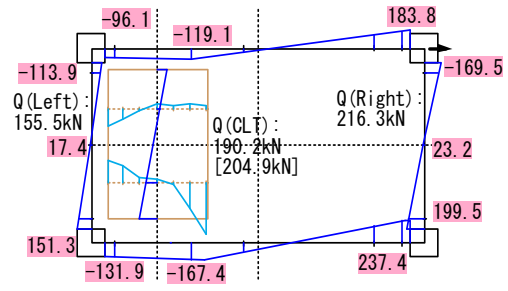

$\underline{\text { Test Result (S60-E1 } \mathrm{P}=561.9 \mathrm{kN})}$

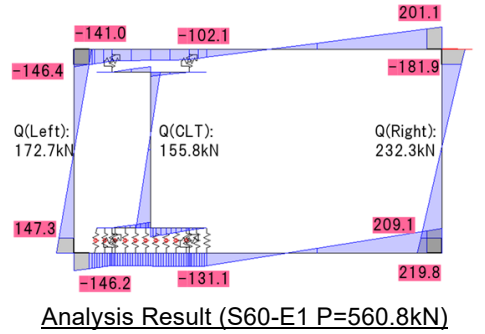

Fig.19 Bending moment and shearing force

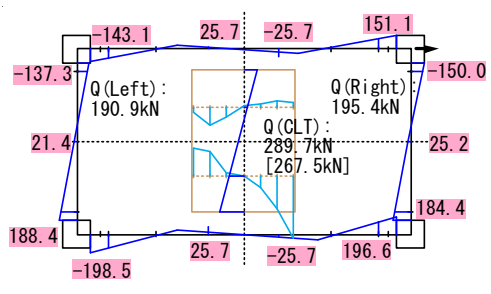

Test Result (S90-C1 $\mathrm{P}=676.0 \mathrm{kN}$ )

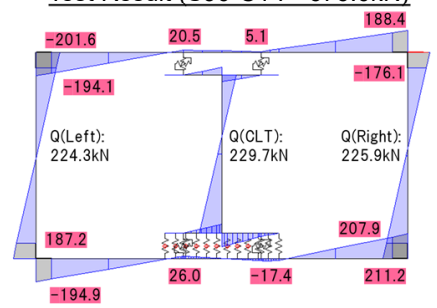

Analysis Result (S90-C1 P=679.9kN) 
なお、CLT を模した線材要素の高さを $1531 \mathrm{~mm}$ とすると支圧バネ の $200 \mathrm{~mm}$ 分が重複して剛性を低く評価することになるが、全体に 占めるその影響は小さいと考え、CLT 線材要素の高さは $1531 \mathrm{~mm}$ のままとしている。

CLT を挿入した試験体(S60-C1、S60-E1、S90-C1)の実験結果と 解析結果を荷重変位関係として、Fig.18 に示す。さらに制御変形角 $1 / 100 \mathrm{rad}$ での実験及び同等の水平力 $P$ が作用するときの解析結果 の曲げモーメント図と柱・CLT の負担せん断力を Fig.19 に、また Fig.19 の凡例を Fig.17 に示す。S60-C1 について、解析結果は実験 結果と比べて初期剛性が少し大きく出ているものの、崩壊メカニズ ム、荷重変形関係は概ね一致した。CLT パネルのせん断力負担割合 は 10\%ほど小さい結果となった。

他の試験体でも同様に崩壊メカニズムが一致した。S60-C1,S90C1 では、最初に鉄骨が降伏し、そのあとCLT のせん断耐力に達し た。S60-E1 も最初に鉄骨はりの端部が降伏して CLT はせん断耐力 に至らないという実験結果と一致した。荷重変形角関係についても 解析が実験結果より少し剛性が高くみられる傾向にあったが、これ はドリフトピン接合部やボルト接合部などの施工のクリアランスが あることを考慮していないためと考えられる。

\section{6. まとめ}

本報では、鉄骨架構に CLT 耐震壁を挿入した構造について、1/2 縮小試験体を対象に実験を行い、その挙動把握を行った。結果を要 約し以下に示す。

1）全ての試験体で、CLT の面内せん断基準強度 $2.70 \mathrm{~N} / \mathrm{mm}^{2}$ 以 上の耐力が得られた。

2）CLTを中央に配置した試験体では CLT のせん断変形角が 0.01rad 付近のときせん断破壊が生じ、多少耐力が低下した。ま た設計上は曲げ破壊が生じていると考えられ、部分的な CLT の 圧壊も観察されたが、履歴特性にスリップ性状があらわれるよう なことはなかった。

3) CLT の強度等級が S90 のものは剛性が高いことが確認でき、要 素試験におけるせん断弾性係数の比率と同程度となった。

4）CLT を端に配置するとせん断破壊が顐著にはみられず、接合部 で集合破壞が生じたものの大きな応力低下は見られなかった。 以上の通り、CLT を用いて、CLT のせん断耐力を十分に発揮でき る耐震壁が鉄骨架構と組み合わせることにより可能とわかった。

さらに、構面実験において使用した材料の要素実験を実施し、試 験体の材料特性を明らかにするとともに、構面実験を再現する解析 モデルを作成し、実験結果と比較した。解析結果が実験結果と概ね 一致することを確認した。

なお、解析と実験結果の応力状態などは、ここには詳しくは記載 していないが、概ね実験結果の挙動を再現していた。ただし、解析 モデルでは、鉛直力を負担するドリフトピン接合部のみをモデル化 し、せん断伝達用のドリフトピン部分はモデル化していない影響で、 解析モデルの CLT の負担せん断力が多少低かった。今後、接合部バ ネ要素を改善するなど実験結果をより正確に再現できるようモデル 化手法、与える定数などを詳細に検討する。加えて、設計用モデル についても提案の予定である。

\section{謝辞}

本研究は林野庁平成 30 年度 CLT 等新たな木質建築部材利用促 進・定着委託事業により実施されました。ここに謝意を表します。

\section{参考文献}

1) Dot Corporation: Development report of seismic wall construction technology for non-wooden buildings using wood-based materials such as CLT, 2017.3 (in Japanese)

株式会社ドット・コーポレーション:平成 28 年度林野庁委託事業 CLT 等 の木質系材料による非木造建築物の耐震壁構成技術の開発報告書，2017.3

2) Fukumoto, K., et al: A Case Study and Future Subjects of Steel Frame Hybrid Structure with CLT Infill Shear Walls, AIJ Journal of Technology and Design, vol.26, No.64, pp.923-928, 2020.10 (in Japanese)

福本晃治、國府田まりな、齋藤真美、岡崎智仁、五十田博、安井昇：CLT 而 震パネルを組み込んだ鉄骨ハイブリッド構造の設計事例と抽出された課題, 日本建築学会技術報告集，第 26 巻，第 64 号，pp. 923-928，2020. 10

3) Miki, N., et al: Cyclic Loading Test of CLT-Steel Hybrid Structure Frame with Connections to Improve Hysteretic Behavior, AIJ Journal of Technology and Design, vol.27, No.65, pp. 213-218, 2021.2 (in Japanese)

三木徳人、中島昌一、山崎義弘、石原直 : 履歴特性の改善を目指した接合部 を有するCLT-鉄骨混構造架構の繰り返し載荷実験, 日本建築学会技術報告 集，第 27 巻，第 65 号, pp. 213-218, 2021.2

4) Committee to Edit Design and construction manual of building using CLT: Design and construction manual of building using CLT, Japan Housing and Wood Technology Center, 2016.10 (in Japanese) 公益財団法人日本住宅・木材技術センター，2016 年版 CLT を用いた建築 物の設計施工マニュアル，2016.10

5) Architectural Institute of Japan: Standard Design of Timber Structures, pp.222-256, 2006. 12 (in Japanese)

一般社団法人 日本建築学会、木質構造設計規準・同解説一許容応力度・許 容耐力設計法一, pp. 222-256, 2006. 12

6) Nakashima, S., et al: Evaluation of Tensile Performance of Drift Pinned Joint with Steel Plate on Cross Laminated Timber, Journal of Structural and Construction Engineering (Transactions of AIJ), vol. 78, No. 687, pp.969-975, 2013.5 (in Japanese) 中島昌一、北守顕久、小松幸平:クロス・ラミネイティド・ティンバーを用 いた鋼板挿入ドリフトピン接合部の引張加力下の耐力指標の検討, 日本建 築学会構造系論文集 第 78 巻, 第 687 号, pp. 969-975, 2013.5

7)Miura, S., et a1. : Lateral Structural Performance of Narrow Size Cross Laminated Timber Connected with Tensile Bolts, Journal of Structural and Construction Engineering (Transactions of AIJ), vol. 81, No.721, pp. 585-593, 2016.3 (in Japanese) 弥浦壮太、五十田博、槌本敬大、中川貴文、北守顕久、鈴木圭、津田千尋： 小幅パネル引きボルト接合したCLT 壁の水平力に対する挙動, 日本建築学 会構造系論文集 第 81 巻，第 721 号，pp. 585-593，2016. 3 


\author{
Kazumi KANAZAWA ${ }^{* 1}$, Hiroshi ISODA ${ }^{* 2}$, Akihisa KITAMORI ${ }^{* 3}$, \\ Tetsu USAMI* ${ }^{* 4}$ and Yasuhiro ARAKI*5 \\ ${ }^{1}$ R.\&D. Institute, Takenaka Co., M.Agr. \\ 2 Prof., RISH, Kyoto University, Dr.Eng. \\ ${ }^{3}$ Assoc. Prof., Faculty of Engineering, Osaka Sangyo University, Dr.Agr. \\ ${ }^{4}$ R.\&D. Institute, Takenaka Co., Dr.Eng. \\ ${ }^{5}$ Senior Researcher, NILIM, Dr.Eng.
}

In Japan, Cross Laminated Timber (CLT) is attracting attention as the way of using forest resources that have reached cutting time. CLT is expected to be used for middle-to-high-rise building with making use of stable in-plane shear performance. In particular, composite structure with steel frame structure or reinforced concrete structure can take adventage of respective material properties, and more and more this kind of researches are reported in recent years. A previous research shows the estimation of drift-pin joint with steel plate for fastening CLT and steel frame. This research aims to confirm the structural performance of steel frame with CLT shear wall using drift-pin joint by conducting the design for this specification, pre-analysis for experiment, 1/2 scale experiment, joint test and material test, and to make analysis model which follows the experimental result.

Firstly, one specification of the joint is defined based on the research of Ministry of Agriculture, Forestry and Fisheries conducted in 2016. It was assumed to insert CLT into a standard span steel frame at the design stage. The design stage takes following steps. 1) Determination of cross section of steel frame and module 2) Determination of CLT type 3) Design of joint 4) Grasp the properties of drift-pin joint 5) application to experimental scale. We use finite element analysis software (SNAP) at $3 \& 5$ step to model a drift-pin joint based on beam theory on the elastic foundation and get load-displacement relationship of unit drift-pin joint. SNAP was also used to analyze the $1 / 2$ scaled experiment to model a steel frame, CLT panel, spring of drift-pin joint, and CLT compression spring, and incremental analysis.

In $1 / 2$ scale experiment, in total of four specimen in different strength grade of CLT or insertion position as parameters are tested. Fig.9 shows the results of the experiment. None of the specimens significantly reduced the load before reputation of controlled deformation angle of 1/30 rad. By inserting a CLT panel, the maximum load increased 1.2 to 1.4 times and the initial stiffness increased 1.5 to 2.3 times, confirming that inserted CLT panel performed as a seismic wall sufficiently. The stiffness of the average shear stress of the CLT almost matched with the shear modulus of the CLT in the material experiment (Fig.11)

Fig.15 shows the analysis model after the experiment using the material properties which is obtained from material tests. Fig.18 shows the Comparison of the experiment to analysis results. The experimental results and the analytical results were in good agreement, and the behavior was able to be reproduced by the analytical model, comparing the timing of yielding of the members and the stress state at the specific deformation angle.

(2021 年 1 月 8 日原稿受理, 2021 年 6 月 22 日採用決定) 